\title{
Application of Imidazolic Polymers to Paint
}

\author{
Katsuo Akagane, Kazuyo Matsuura \\ and G. G. Allan \\ Kansai Paint Co., Ltd.* \\ Univ. of Washington**
}

\begin{abstract}
1-hydroxylimidazoles were synthesized by the action of ammonia on an equimolecular solution of the aldehyde and the $\alpha$-dione monoxime, and also its oxides were prepared by the condensation of two moles of hydroxylamine hydrochlopide with an equimolecular solution of the aldehyde and the $\alpha$-dione.

Among them, it was found out that 1-hydroxy 2-(6-methyl-2-pyridyl) 4, 5-dimethylimidazole only had the photochromic behavior. Therefore, the film prepared by addition of the imidazole to the chlorinated rubber also showed the photochromism and its rate constant was $0.9 \times 10^{-2} \mathrm{sec}^{-1}$. The hydroxyl function in 1-hydroxylimidazoles and their oxides was treated with acrylic chloride to the acryloxy group.

The copolymers between acryloxyimidazoles or oxides and styrene were obtained.

From the results of the immersion tests and the adhesion tests after exposure of the painted specimens, it was recognized that the introduction of imidazole ring to system could improve the both qualities.
\end{abstract}

* 5-27, Fushimi, Higashi-ku, Osaka

** Seattle, Wash. 98105. Univ. of Washington 


\title{
イミダゾール系ポリマーの塗料への応用
}

\author{
赤金華津男* ・松浦和代* . G. G. Allan**
}

\begin{abstract}
要旨
1-オキシイミダท゙ールは $\alpha$-ジオンモノオキシム類とアルデヒド類をアンモニアと縮合 して, またそのオキシドは $\alpha$-ジオン類とアルデヒド類をヒドロキシルアミン塩酸塩と縮 合してそれぞれ合成した。そのうち 1-オキシ 2-(6-メチル-2-ピリジル) 4, 5-ジメチルイ ミダゾールはホトクロミズムを示した。それを塩化ゴムに混合して得た塗膜はホトクロミ ズムを有し，その速度定数を測定した結果 $0.9 \times 10^{-2} \mathrm{sec}^{-1}$ を得た。

1-オキシイミダヅール怙よびそのオキシドの水酸基はアクリル酸クロリドと反応させて アクリル化した。それとスチレンの共重合を試み, 得られたポリマーについて耐塩水性拈 よび暴露付着性を検討した結果, イミダท゙ール環を導入することによりいずれの性能も向 上することを認めた。
\end{abstract}

\section{1. 緒言}

ヘテロ環, 特に窒素原子を有する塗料用樹脂の研究は トリアジン系を除いてはあまり多くない。その一つの理 由として， ヘテロ環化合物のコストが高く実用化に至っ ていないことも考觉られよう。そこで本報ではイミダヅ ール系化合物の簡便な合成法とそのポリマーの開発研究 を試みた結果，二，三の興味ある知見が得られたので報 告する。

\section{2. 実験}

\section{1 試 薬}

試薬は特に注のないかぎり Aldrich Chem. 製品をそ のまま使用した。

\section{2 合 成}

2.2 .1 1-オキシイミダท゙ールの一般合成

アルデヒド類と $\alpha$-ジオンモノオキシム類の等モル量 をメタノールに混溶後等モル量のアンモニア水を用いて 縮合した。この反応は発熱するので温度は $60^{\circ} \mathrm{C}$ 以下に 保ち, かきまぜながら約 2 時間反応させ, 反応後過剩量 の溶剤を減圧して除くと析出物が得られる。それを採集 しメタノールまたはアセトンで再結晶する。(表-1 参照)

昭和 46.7 .22 受理

* 関西ペイント株式会社 大阪市東区伏見 5-27

** Univ. of Washington Seattle, Wash. 98105. U.S.A
実例：1-オキシ-2-(6-メチル-2-ピリジル) 4,5-ジメ チルイミダゾール ( $\mathrm{I})$ 。

6-メチル-2-ピリジンカルボキシアルデヒド $(48.4 \mathrm{~g}$, 0.40 モル) と 2,3-ブタンジオンモノオキシム（40.4g， 0.40 モル) を $95 \%$ エタノール $(2.5 l)$ に溶解後, アン モニア水 (d. $0.88: 40 \mathrm{ml}$ ) を加え, 常温にてかきまぜ ながら約 2 時間反応した。過剰溶剤を減圧加熱にて除去 し, 冷所にて一夜放置後析出した化合物をメタノールで 再結晶して，プリズム状結晶， $50.4 \mathrm{~g}$ を得た。 $\mathrm{mp} 149$ $152^{\circ}$ このイミダゾールはホトクロミズムを示した。赤 外線吸収スペクトルを図-1 に示す。

分析值 C : $64.82 \%, \mathrm{H}: 6.32 \%, \mathrm{~N}: 20.40 \%$, $\mathrm{C}_{11} \mathrm{H}_{13} \mathrm{~N}_{3} \mathrm{O}_{1}$ としての計算值, $\mathrm{C}: 65.02 \%, \mathrm{H}: 6.40 \%$, $\mathrm{N}: 20.69 \%$ 。

2.2 .2 1-オキシイミダゾール 3 オキシドの一般合成 アルデヒド類と $\alpha$-ジオン類の等モル量を $95 \%$ エチル アルコールに混溶後 2 倍モル量の粉状ヒドロキシルアミ ン塩酸塩を加え温浴上にてかきまぜた。反応が進むにつ れヒドロキシルアミン塩酸塩の沈殿は溶解した。 $2 \sim 4$ 時間反応後, 炭酸ナトリウムを加えて中和した。溶剤を 減圧加熱で除去し, 沈殿物をメタノールで抽出した。抽 出液を減圧乾燥して得られた析出物を, 再びメタノール にて再結晶する。（表-2 参照）

実例：1-オキシ-2-(6-メチル-2-ピリジル) 4,5-ジメ チルイミダゾール 3-オキシド $(\mathrm{X})$ 。

2,3-ブタンジオン $(8.6 \mathrm{~g}, 0.1$ モル $)$ と 6-メチル-2-ピ リジンカルボキシアルデヒド $(12.1 \mathrm{~g}, 0.1$ モル)をメタ

$40 \quad[3]$ 

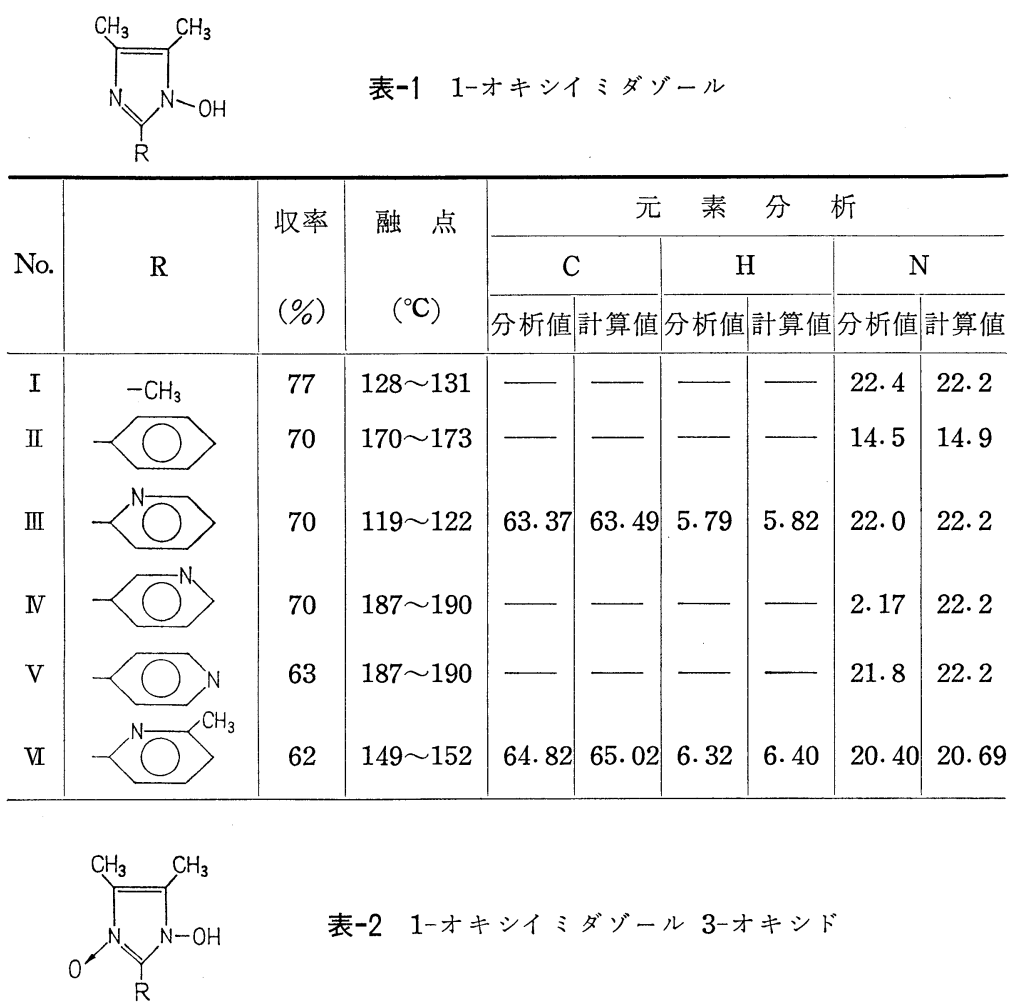

表-2 1-オキシイミダゾール 3-オキシド

\begin{tabular}{|c|c|c|c|c|c|c|c|c|c|}
\hline \multirow{3}{*}{ No. } & \multirow{3}{*}{$\mathrm{R}$} & \multirow{3}{*}{$\begin{array}{l}\text { 収率 } \\
(\%)\end{array}$} & \multirow{3}{*}{$\begin{array}{c}\text { 融 点 } \\
\left({ }^{\circ} \mathrm{C}\right)\end{array}$} & \multicolumn{4}{|c|}{ 元 } & 析 & \\
\hline & & & & \multicolumn{2}{|c|}{$\mathrm{C}$} & \multicolumn{2}{|c|}{$\mathrm{H}$} & \multicolumn{2}{|c|}{$\mathrm{N}$} \\
\hline & & & & 分析値 & 計算値 & 分析値 & 計算值 & 分析値 & 計算値 \\
\hline VII & $-\mathrm{CH}_{3}$ & 83 & 199 & 50.71 & 50.70 & 7.00 & 7.04 & 19.68 & 19.71 \\
\hline VIII & & 98 & $168 \sim 171$ & - & $\longrightarrow$ & - & - & 13.69 & 13.72 \\
\hline $\mathbb{X}$ & & 73 & $205 \sim 208$ & - & - & - & - & 20.00 & 20.50 \\
\hline $\mathrm{X}$ & & 70 & $168 \sim 170$ & 59.98 & 60.25 & 6.07 & 5.94 & 19. 07 & 19.18 \\
\hline
\end{tabular}

ノール $(200 \mathrm{~m} l)$ に混溶し, 粉状 ヒドロキシルアミン塩酸塩 (13.9 g, 0.2 モル）を加え温浴上にてか きまぜた。約 2 時間後炭酸ナトリ ウム $(25 \mathrm{~g})$ を加えた。溶剤を減 圧加熱で除去後, 再びメタノール $(200 \mathrm{ml})$ 飞溶解し, 不溶物を口 別した。尸液を減圧のもとに濃縮 することにより得られた析出物を 口集し,メタノールで再結晶して 針状結晶 $14.0 \mathrm{~g}$ を得た。 mp 168 $\sim 170^{\circ} \mathrm{C}$, この赤外線吸収スペク トルを図-2 に示す。

分析値 $\mathrm{C}: 60.21 \%, \mathrm{H}: 6.00$ $\%, \mathrm{~N}: 19.07 \%, \mathrm{C}_{11} \mathrm{H}_{13} \mathrm{~N}_{3} \mathrm{O}_{2}$ そ しての計算值 : C : $60.27 \%, \mathrm{H}$ : $5.94 \%, \mathrm{~N}: 19.18 \%$

\section{2 .3 モノマーの合成}

ジオキサン (6 部), ピリジン (2 部), ジメチルホルムアミド （2 部）の混合溶剤中に 1-オキシ イミダゾールをたはオキシドを溶 解し, 常に $15^{\circ}$ 以下に保ち, かき まぜながらアクリル酸クロリドを 徐々に加えてアクリル化した。工 ーテルを加えドライアイスを用い て冷却すると析出物（ジオキサン とともに）が現われた。ジオキサ ンを減圧除去後, 得られた析出物 を口集した。少量のピリジンで再 溶解しエーテルを加えて析出させ た。口集した結晶をデシケーター 中 $\mathrm{P}_{2} \mathrm{O}_{5}$ 上で乾燥した。(表-3参照)

2.2 .4 ポリマーの合成

表-3 のモノマーと常法で精製したスチレ ンとの各割合の混合物をジメチルホルムアミ ドに混溶後重合管に入れ，開始剤としてアゾ ビスイソブチロニトリル (AIBN) をモノマー 1 モル当たり $4 \times 10^{-4}$ モル 加えた。窒素ガス 流入後密センし, $70^{\circ} \mathrm{C} に 2$ 日間放置した。 得られたポリマーはエーテルと冷水で交互に 数回洗浄した。その結果を表-4, 5 に示す。

\section{2 .5 キレート化合物}

1-アクリルオキシー2-(2-ピリジル) 4,5 -ジ メチルイミダゾール $(3.65 \mathrm{~g}, 0.015$ モル)を 


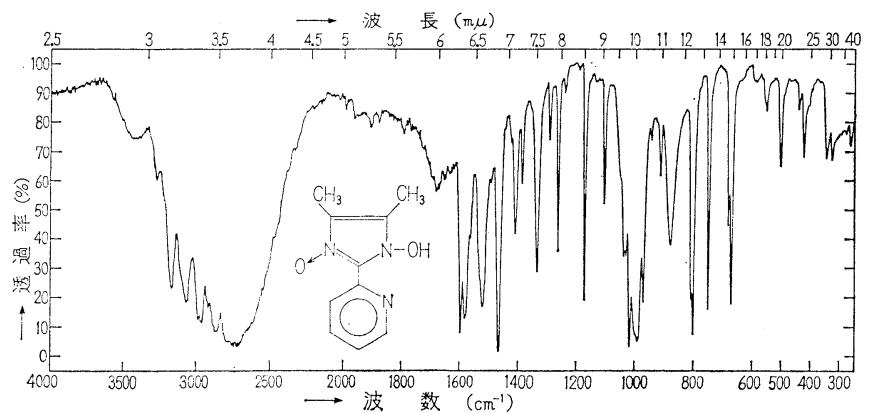

図-2 オキシー2-(6×xチル-2-ピリジル) 4, 5-ジメチルイミダท゙ール

3ーオキシドの赤外線吸収スペクトル

塩化第二鉄 $(2.70 \mathrm{~g}, 0.010$ モル)の水溶液 $(300 \mathrm{ml})$ に 溶解した。数時間室内に放置後, 生じた沈殿物をロ集 し, 冷水执よびアセトンで洗浄後, 減圧乾燥してカッ色 粉状結晶 $3.5 \mathrm{~g}$ を得た。 $\mathrm{mp} 300^{\circ} \mathrm{C}<$

分析值 $\mathrm{N}: 14.42 \%, \mathrm{Fe}: 9.63 \%$

$\mathrm{C}_{25} \mathrm{H}_{26} \mathrm{~N}_{6} \mathrm{O}_{4} \mathrm{Fe}_{1} \cdot 2 \mathrm{H}_{2} \mathrm{O}_{1}$ としての計算值 $\mathrm{N}: 14.53 \%$,

$\mathrm{Fe}: 9.66 \%$

鉄含有量はアルカリ処理後強熱して酸化鉄としてヒョウ 量して算出した。

\section{3 塗装試料と試験片の調製}

キシレン：メチルエチルケトン：エチルアルコール （6:3:1）の混溶剤にポリマーを溶解し $20 \%$ 溶液とし, ベンガラ $20 \mathrm{~g}$ を加えて振とう機で分散した。試験片は。 $0.5 \times 100 \times 100 \mathrm{~mm}$ の軟鋼板をエメリ一紙研摩してさら

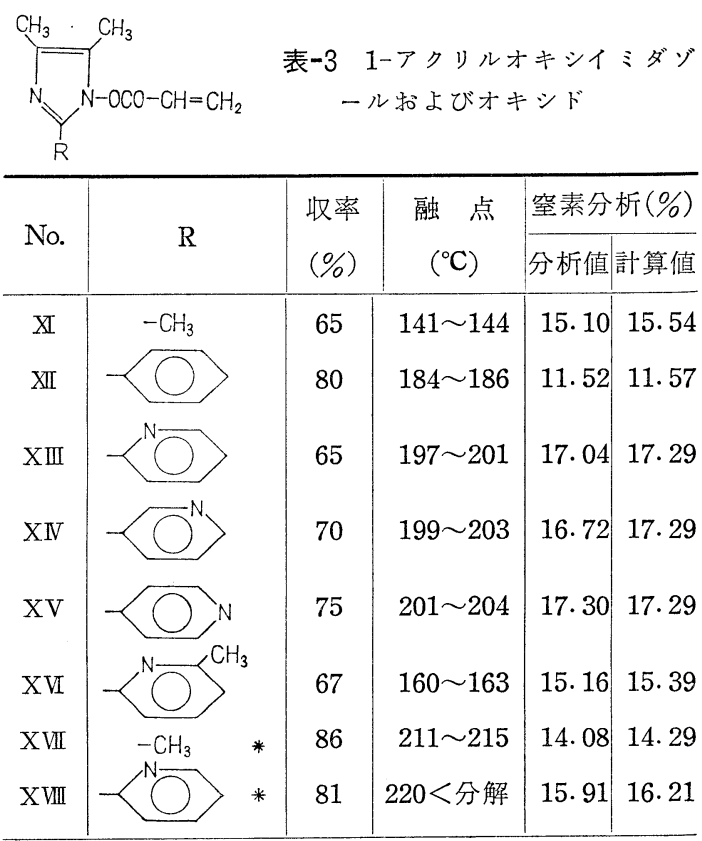

注）*:イミダゾールオキシド
に脱脂を行なったのち, 所定の厚さ（約 0.1 $\mathrm{mm}$ ) になるように試料を塗布した。

大気暴露は常法に従い南面 $45^{\circ}$ で行なっ た。耐塩水性用試験片は周辺をミシロウー松 脂混合物で被覆し, 塗面に $8 \mathrm{~cm}$ 幅 $35^{\circ}$ のク ロスカットを入れて $3 \%$ 食塩水浴に浸せキし た。

\section{4 耐塩水性および付着性試験}

暴露試験片の付着性をゴバン目試験により 評価した。実験は 2 回以上の繰り返しを行な いその平均值をとった。耐塩水性は塗膜のフ クレクロスカット部からのハガレの状態により次のよ らに表示した。
$\mathrm{A} ：$ フクレ，ハガレなし
$\mathrm{B}: \phi 2 \mathrm{~mm}$ 以内のフクレが 5 個以内の場合, カット部にわずかのハガレがある場合 $\mathrm{C} ： \mathrm{~B}$ 以上のフクレ，ハガレがある場合

表-4 XIII とスチレンとのコポリマー

\begin{tabular}{|c|c|c|c|c|}
\hline No. & $\begin{array}{l}\text { コモノマー } \\
\text { 中の XIII } \\
(\text { モル\%) }\end{array}$ & $\begin{array}{c}コ \text { コ゚リマー } \\
\text { の取率 } \\
(\%)\end{array}$ & $\begin{array}{l}\text { コポリマー } \\
\text { 中の窒素含 } \\
\text { 有量 }(\%)\end{array}$ & $\begin{array}{l}\text { コポリマー } \\
\text { 中の XII } \\
(\text { モル \%) }\end{array}$ \\
\hline $\mathrm{XXX}$ & 0 & - & 0 & 0 \\
\hline XX & 10.0 & 63.0 & 3.1 & 8.5 \\
\hline XXI & 20.0 & 51.8 & 4.7 & 13.9 \\
\hline XXII & 30.0 & 48.2 & 6.5 & 20.3 \\
\hline
\end{tabular}

$\sum_{\mathrm{R}-0-\mathrm{CO}-\mathrm{C} H}^{\mathrm{C}}$ 表-5 スチレンとのコポリマー

\begin{tabular}{|c|c|c|c|c|c|}
\hline No. & $\mathrm{R}$ & & $\begin{array}{c}\text { コポリマ- } \\
\text { の収率 } \\
(\%)\end{array}$ & $\begin{array}{l}\text { ᄀポリマー } \\
\text { 中の窒素含 } \\
\text { 有量 (\%) }\end{array}$ & $\begin{array}{l}\text { ユポリマ } \\
\text { 中の XII } \\
(モ ル \%)\end{array}$ \\
\hline XXIII & $-\mathrm{CH}_{3}$ & & 47.3 & 3.6 & 13.5 \\
\hline XXIV & & & 54.0 & 3.2 & 14.2 \\
\hline $\mathrm{XXI}$ & & & 51.8 & 4.7 & 13.9 \\
\hline XXV & & & 45.0 & 4.4 & 12.6 \\
\hline XXVI & & & 49.5 & 4.5 & 13.0 \\
\hline XXVII & & & 42.4 & 4.1 & 11.8 \\
\hline XXVIII & $-\mathrm{CH}_{3}$ & * & 37.0 & 3.1 & 13.0 \\
\hline XXIX & & & 40.5 & 4.1 & 12.0 \\
\hline
\end{tabular}

1）表-4 中の值を再記入した。

*イミダゾールオキシド 


\section{3. 結果および考察}

\subsection{1ーオキシイミダゾールの合成}

Diels らは 2.3-ブタンジオンモノオキシムとアルデヒ ドをアンモニアで縮合して窒素を含有するへテロ環化合 物を得た ${ }^{1)}$ 。その構造として(a)を与兄たが，著者らが

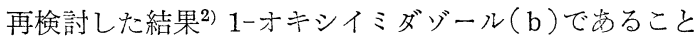
がわかった。
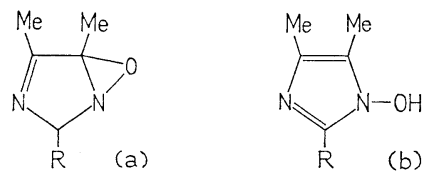

この縮合は次のような反応機構によると推定する。<smiles>[R]C(=O)OCC</smiles><smiles>[R]C(N)NC=C</smiles><smiles></smiles><smiles>C#CN1N=C(C)C2(C)CC1=NO2</smiles>

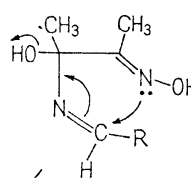<smiles>[2H]c1nc(C)c(C)n1O</smiles>
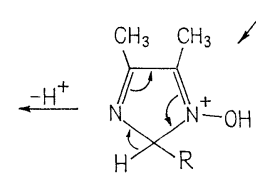

かようにして合成された 1-オキシイミダゾールを表-1 にまとめた。

\subsection{1ーオキシイミダソール 3 オキシドの合成}

1ーオキシイミダゾール 3 オキシドの合成については

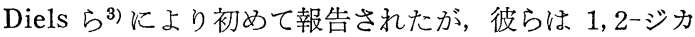
ルボニルモノオキシム類とアルドキシム類とを酸触媒の もとに反応させてイミダゾールオキシドを得ている。そ の後 $\mathrm{LaParola}^{4)}$ はグリオキシムとアルデヒドとを酸触 媒のもとで反応させ, 同様にイミダジールオキシドを得 たと報告している。

Diels の方法<smiles>[R]C=NO[NH2+][CH+][R]c1c([R])n(O)c([R])[n+]1[O-]</smiles>

La Paro La の ○

$$
\prod_{\mathrm{N}-\mathrm{OH}}^{\mathrm{R}}+\mathrm{R}^{\prime} \mathrm{CH}: 0
$$

しかしながらいずれの方法ににしても 1,2-ジカルボニ ル化合物をオキシムの形にしなければならないし，特に
Diels の方法ではアルデヒドもアルドキシムにしなけれ ばならない。それゆ穴総収率の低下, 合成工程の手数は 免れない。そこでもしもアルデヒドと 1,2-ジカルボニ ル化合物の等モル混合物に 2 倍モル量のヒドロキシル ミン塩酸塩を作用させた場合に良収率でイミダゾールオ キシドを与えるならば合成工程の手数と時間の単縮とな る。実際に期待通りの反応が起こるかどうか, La Parola による方法で合成した 1-オキシ-2-(6-メチル-2-ピリジ ル） 4, 5-ジメチルイミダゾール 3-オキシド (X) と新合 成法により得られた化合物の比較検討した結果, 同一物 であることを確認した。すなわち赤外線吸収スペクトル はいずれの吸収もよく一致を示し，また両方の混合物を 混融しても融点降下を示さなかった。元素分析値もよく 理論値と一致している。次に得られたXをホウ水素ナト リウムによる還元占を試みた。メタノール中で常温で還 元した結果 1-オキシ-2-(6-メチル-2-ピリジル) 4, 5-ジ メチルイミダゾールを得た。この化合物は 2.2 .1 の方法 で合成されたものと同一物であることを分析の結果確認 した。

本報の合成法は 1,2 -ジカルボニル化合物とアンモニ アおよびアルデヒドを縮合してイミダゾールを合成する 方法6)とよく類似している。すなわちアンモニアの代わ りにヒドロキシルアミンを使らだけである。

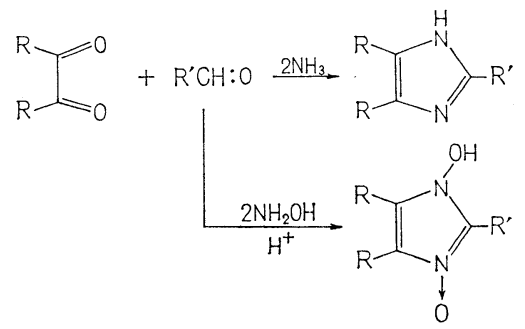

さらにこの合成反応を次のように幅広く広げられること がわかった。

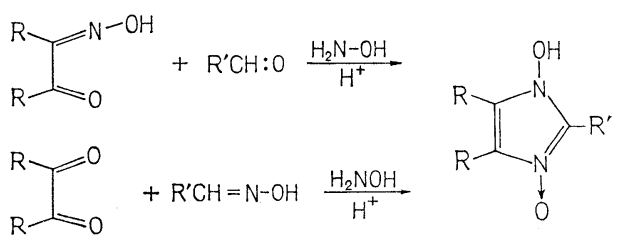

\section{3 ホトクロミズム}

1-オキシ-2(6-メチル-2-ピリジル) 4, 5-ジメチルイミ ダゾール（VI) はホトクロミズムを示した。すなわち暗 所では淡黄色であるが日光または紫外線ランプ下に曝す 々紫色に転じ，この変化は可逆的であった。この化合物 の水酸基をアクリル化して高分子体にすることを試みた が、アクリル体・ポリアクリル体のいずれるホトクロミ 


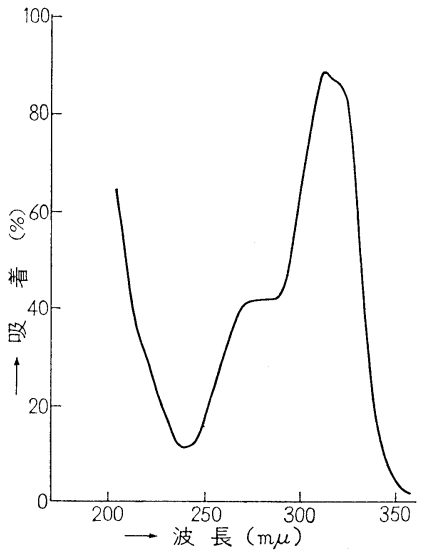

図-3 紫外線吸収スペクトル

ズムを示さなかった。このことと紫外線吸収スペクトル (図-3 参照) から Vの水酸基はホトクロミズムに関与し ていると考光, 著者らは次のような機構を推定する。

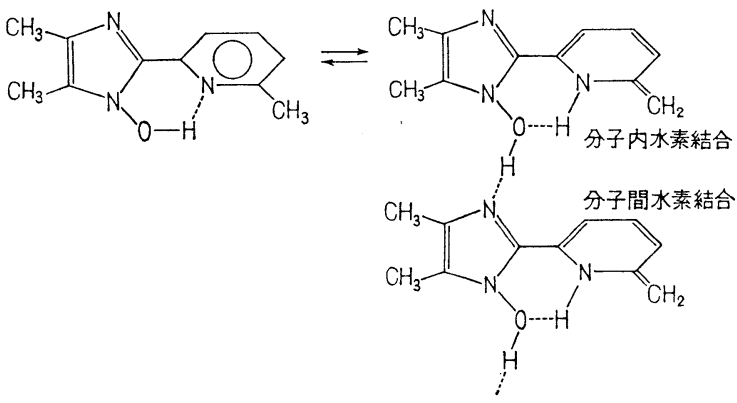

ホトクロミックな塗膜を得るために，市販塩化ゴム (Parlon; Hercules Powder Co. 製) をキシレンーミネ ラルスピリット（1：1）に溶解して 20\% ワニスにし, このワニス $100 \mathrm{~g}$ に政 $10 \mathrm{~g}$ 加えて振とう機でよく分散 した。この試料をパルプ紙 $(3 \times 50 \times 100 \mathrm{~mm})$ に塗布し, 常乾後ホトクロミズムの程度を調べた。すなおち試片を キセノンランプで照射し, 各照射時間ごとに塗面の写真 (ニコン F，フォトマチック $\mathrm{F} を$ 用いて）を撮り，その濃 淡の程度をミクロデンシトメーター(MK III C-Joyce, Loeble and Co. 製) で読み取り速度定数を次式に従って 算出した。このホトクロミズムを一次反応と仮定するな らば照射時間 $(t)$ とミクロデンシトメーターの示す濃 さ (d) との間には次式が成り立つ7),

$$
\begin{aligned}
\ln \left(d_{\infty}-d_{0}\right) /\left(d_{\infty}-d\right)=k t \\
d_{0}: \text { 照射前の塗面の濃さ } \\
d_{\infty}: \text { 無限照射後の濃さ } \\
k: \text { 速度定数 }
\end{aligned}
$$

図-4 から式（1）をよく満足していることがわかる。そ の結果速度定数として $0.9 \times 10^{-2} \mathrm{sec}^{-1}$ を得た。

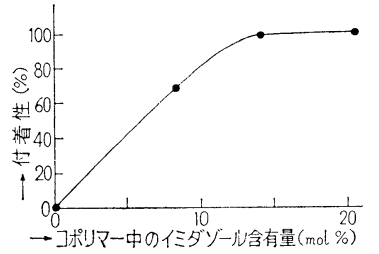

図-5 コポリマー中のイミダゾー ル含有量と付着性の関係

注）表-4 および 6 の結果を用い

\begin{tabular}{|c|c|c|c|c|}
\hline \multirow{2}{*}{$\begin{array}{c}\text { 試 料 } \\
\text { No. }\end{array}$} & \multicolumn{2}{|c|}{3 力 月 } & \multicolumn{2}{|c|}{6 力 月 } \\
\hline & 耐塩水 & 付 着 性 & 耐塩水 & 付 着 性 \\
\hline $\mathrm{XIX}$ & B & $10 / 100$ & $\mathrm{C}$ & $0 / 100$ \\
\hline $\mathrm{XX}$ & A & $80 / 100$ & B & $70 / 100$ \\
\hline XXI & A & $100 / 100$ & A & $100 / 100$ \\
\hline XXII & A & $100 / 100$ & A & $100 / 100$ \\
\hline $\mathrm{XXN}$ & A & $90 / 100$ & B & $70 / 100$ \\
\hline XXV & A & $100 / 100$ & A & $95 / 100$ \\
\hline XXV & A & $100 / 100$ & A & $95 / 100$ \\
\hline XXIX & A & $95 / 100$ & B & $80 / 100$ \\
\hline
\end{tabular}
て再プロットした。( 6 カ月暴 露後のゴバン目付着性)

表-6 耐塩水特よび暴露付着性試験結果

3.4 耐塩水性および暴露付着性。（表-6, 図-5 参照）

いずれの性能もイミダゾー ル基を導入することにより向 上することがわかった。特に 2-ピリジルの場合，すぐれた 付着性を有していた。その理 由として鉄面とのキレート生 成が考学られる。この点を明

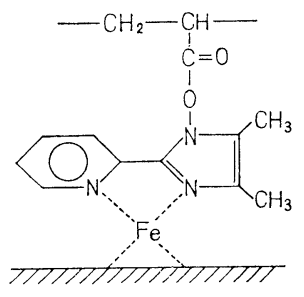
らかにするためモデル化合物として 1-アクリルオキシー 2-(ピリジル) 4,5-ジメチルイミダゾールを塩化第二鉄 の水溶液と反応させて得られた錯体は分析の結果, 二分 子のイミがゾールが鉄イオン（II）に結合していることが わかった。この安定度定数に関しては今後検討したい。

\section{文献}

1) O.Diels, Ber., 51, 965 (1918)

2) K. Akagane et al., Bull. Chem. Soc. Japan, 42, 3204 (1969)

3) O. Diels, R. van der Leeden, Ber., 38, 3363 (1905)

4) G. LaParola, Gazz. chim. ital., 75, 216 (1945)

5）赤金華津男, 日化投稿中

6) H.Debus, Ann., 107, 204 (1858)

7) G. Allan, K. Akagane, J.Bindra, unpublished work. 